\title{
Determination of olanzapine by spectrophotometry using permanganate
}

\author{
Nagaraju Rajendraprasad, Kanakapura Basavaiah*
}

Department of Chemistry, University of Mysore, Manasagangothri, India

\begin{abstract}
Two new spectrophotometric methods using permanganate as the oxidimetric reagent for the determination of olanzapine (OLP) were developed and validated as per the current ICH guidelines. The methods involved the addition of known excess of permanganate to OLP in either acid or alkaline medium followed by the determination of unreacted permanganate at $550 \mathrm{~nm}(\operatorname{method} \mathrm{A})$ or bluish-green color of manganate at $610 \mathrm{~nm}$ (method B). The decrease in absorbance in method A or increase in absorbance in method $\mathrm{B}$ as a function of concentration of OLP was measured and related to OLP concentration. Under optimized conditions, Beer's law was obeyed over the ranges 2.0 to 20 and 1.0 to $10 \mu \mathrm{g} \mathrm{mL}^{-1}$ in method A and method B, respectively. The calculated molar absorptivity values were $1.34 \mathrm{x} 10^{4}$ and $2.54 \times 10^{4} 1 \mathrm{~mol}^{-1} \mathrm{~cm}^{-1}$ for method A and method B respectively, and the respective Sandell sensitivities were 0.0233 and $0.0123 \mu \mathrm{g} \mathrm{cm}^{-2}$. The LOD and LOQ for method A were calculated to be 0.37 and 1.13 $\mu \mathrm{g} \mathrm{mL}^{-1}$ and the corresponding values for method B were 0.16 and $0.48 \mu \mathrm{g} \mathrm{mL}^{-1}$. Intermediate precision, expressed as RSD was in the range 0.51 to $2.66 \%$, and accuracy, expressed as relative error ranged from 0.79 to $2.24 \%$. The proposed methods were successfully applied to the assay of OLP in commercial tablets with mean percentage recoveries of $102 \pm 1.59 \%$ (method A) and $101 \pm 1.53 \%$ (method B). The accuracy and reliability of the methods were further confirmed by performing recovery tests via standard addition procedure.
\end{abstract}

Uniterms: Olanzapine/determination. Spectrophotometry. Permanganate. Pharmaceuticals.

Dois métodos espectrofotométricos novos, usando o permanganato como o reagente oxidimétrico para a determinação da olanzapina (OLP) foram utilizados e validados de acordo com as diretrizes atuais do ICH. Os métodos envolveram a adição de excesso conhecido de permanganato à OLP em meio ácido ou alcalino, determinando-se o permanganato que não reagiu em $550 \mathrm{~nm}$ (método A), ou pela cor verdeazulada do manganato a $610 \mathrm{~nm}$ (método B). A diminuição da absorbância no método A ou o aumento da absorbância no método $\mathrm{B}$, em função da concentração de OLP, foi medida e relacionada à concentração de OLP. Sob condições otimizadas, a lei de Beer foi obedecida, nas faixas de concentração de 2,0 a 20 e 1,0 a 10 ao $\mu \mathrm{g} \mathrm{mL}-1$, no método A e no método B, respectivamente. Os valores de absortividade molar foram de 1,34 x 104 e 2,54 x 1041 mol-1 cm-1 para o método A e para o método B, respectivamente, e as sensibilidades respectivas de Sandell foram de 0,0233 e 0,0123 $\mu \mathrm{g} \mathrm{cm}-2$. Os LOD e os LOQ para o método A calculados foram 0,37 e $1,13 \mu \mathrm{g}$ mL-1e os valores correspondentes para o método B foram 0,16 e $0,48 \mu \mathrm{g} \mathrm{mL}-1$. A precisão intermediária, expressa como RSD, encontrou-se na faixa de $0,51 \mathrm{a}$ $2,66 \%$, e a exatidão, expressa como o erro relativo, variou de 0,79 a 2,24\%. Os métodos propostos foram aplicados com sucesso ao ensaio de OLP em comprimidos comerciais, com porcentagens médias de recuperação de $102 \pm 1,59 \%$ (método A) e de $101 \pm 1,53 \%$ (método B). A exatidão e a confiabilidade dos métodos foram confirmadas executando testes de recuperação através de procedimento padrão de adição.

Uniterms: Olanzapina/determinação. Espectrofotometria. Permanganato. Produtos farmacêuticos. 


\section{INTRODUCTION}

Olanzapine (OLP), chemically known as 2-methyl10-(4-methyl-piperazin-1-yl)-4H-3-thia-4,9-diazabenzo[f]azulene (Figure 1), is an atypical antipsychotic drug that belongs to the thienobenzodiazepine class. It shows high receptor affinity binding in vitro at serotonin, dopamine, muscarinic and histamine receptors. Since its introduction in 1997, it has been approved in 84 countries for treating schizophrenia and related disorders (Shen, 1999).

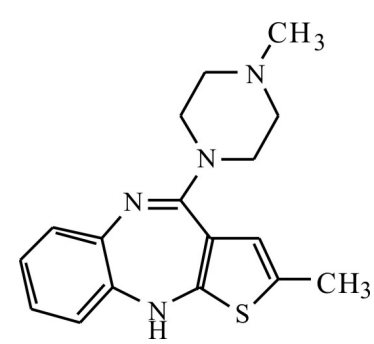

FIGURE 1 - Structure of olanzapine

Several analytical methods have been reported for the determination of OLP in biological fluids and in pharmaceutical preparations, and they include high performance liquid chromatography (HPLC) with ultraviolet (Olesen et al., 1998; Boulton et al., 2001; Harald et al., 2001; Concetta et al., 2006; Dusci et al., 2002; Olesen et al., 2001; Raggi et al., 2000; Saracino et al., 2007; Shah et al., 2007; Reddy et al., 2007; Xuejun et al., 2004); electrochemical (Saracino et al., 2006; Raggi et al., 2000; Bao, Potts., 2001; Raggi et al., 2001; Kasper et al., 1999) or mass spectrometric (Thieme, Sachs., 2003; Berna et al., 2002; Titier et al., 2003; Dusci et al., 2002) detection, gas chromatography (Sabbioni et al., 2004), capillary zone electrophoresis (Raggi et al., 2000), UVspectrophotometry and non-aqueous titrimetry (Firdous et al., 2005). However, there are only three reports on the visible spectrophotometric methods (Jasinska, Nalewajko, 2004; Mohamed, 2008; Krebs et al., 2006) based on redox reaction using hexacyanoferrate (III), cerium (IV), Nbromosuccinimide (NBS) or potassium iodate. However, these methods suffer from one or the other disadvantage such as poor sensitivity, unstable color and rigid experimental conditions (Table I).

The aim of the present work is to develop simple, sensitive and cost-effective spectrophotometric methods for the determination of OLP in pharmaceutical formulations. The methods make use of potassium permanganate as the oxidimetric reagent, and have been demonstrated to be superior to the existing spectrophotometric methods in terms of sensitivity, color stability, working conditions, and accuracy and precision. We have found that potassium permanganate has earlier been used in pharmaceutical analysis in the determination of thioxanthines, for example (Tammilehto, 1980), isoniazid (Murugesan, Venkappayya, 1983) methyl thiouracil (Kucharski, Sikorska-Tomica, 1982) chloramphenicol (Fedchenko, 1985) amidopyrine (Stepnayuk and Balagorazumnya, 1989), valdecoxib (Suganthi et al., 2006), nicotine (Al-Tamrah, 1999) tramadol HCl (Abdellatef, 2002) cefuroxime (Reddy et al., 2002), diloxamide (A1Ghanman, Belal., 2001) and pentacozine (Sastry et al., 1998), to mention a few.

In our studies OLP was found to react with permanganate in $\mathrm{H}_{2} \mathrm{SO}_{4}$ medium consuming the oxidant in proportion to its concentration. This reaction was used for the indirect assay of OLP by measuring the decrease in the absorbance at $550 \mathrm{~nm}$ as a function of the OLP concentration. On the other hand, in alkaline medium, the reaction yielded a bluish-green manganate with a $\lambda_{\max }$ at $610 \mathrm{~nm}$. This color reaction was studied for the direct spectrophotometric determination of the drug. Optimum conditions were established and both the methods were validated for linearity, sensitivity, accuracy and precision as well as robustness and ruggedness. The validated methods when applied to the determination of OLP in tablets yielded results which were in agreement with the label claim.

\section{MATERIAL AND METHODS}

\section{Apparatus}

Absorbance measurements were made with a Systronics model 106 digital spectrophotometer equipped with $1 \mathrm{~cm}$ matched quartz cells.

\section{Reagents and standards}

All chemicals used were of analytical grade and solutions were made in distilled water.

\section{Potassium permanganate $\left(600 \mu \mathrm{g} \mathrm{mL}^{-1}\right)$}

An approximately $0.002 \mathrm{M}$ solution was prepared by dissolving $79.00 \mathrm{mg}$ of $\mathrm{KMnO}_{4}$ (Merck, Mumbai, India) in water and diluting to $250 \mathrm{~mL}$ in a calibrated flask, and standardized using H.A Bright's procedure (Vogel, 1961). The standard solution was then diluted appropriately with water to get $600 \mu \mathrm{g} \mathrm{mL}^{-1}$ working concentration for method A. A separate $0.2 \%$ aqueous solution was prepared for use in method B. 
TABLE I - Comparison of the performance characteristics of the present methods with the published methods

\begin{tabular}{|c|c|c|c|c|c|c|c|}
\hline Sl. No. & $\begin{array}{l}\text { Reagent/s } \\
\text { used }\end{array}$ & Methodology & $\begin{array}{l}\lambda_{\max } \\
(\mathbf{n m})\end{array}$ & $\begin{array}{l}\text { Linear range } \\
\left(\mu \mathrm{g} \mathrm{mL} \mathrm{L}^{-1}\right)\end{array}$ & $\begin{array}{c}\text { LOQ } \\
\left(\mu \mathrm{g} \mathrm{mL} L^{-1}\right)\end{array}$ & Remarks & Ref. \\
\hline \multirow[t]{3}{*}{1.} & $\begin{array}{l}\text { a) Hexacyano } \\
\text { ferrate (III) }\end{array}$ & $\begin{array}{l}\text { Unreacted oxidant } \\
\text { measured }\end{array}$ & 425 & $2.5-40.0$ & - & $\begin{array}{l}\text { Reaction requires } 1: 1 \text { mixture } \\
\text { of } \mathrm{H}_{2} \mathrm{SO}_{4} \text { and } \mathrm{H}_{3} \mathrm{PO}_{4}\end{array}$ & $\begin{array}{l}\text { Jasinska and } \\
\text { Nalewajko } \\
2004\end{array}$ \\
\hline & $\begin{array}{l}\text { b) Hexacyano } \\
\text { ferrate (III) }\end{array}$ & $\begin{array}{l}\text { Radical cation } \\
\text { measured }\end{array}$ & 540 & $0.5-250$ & & Contact time 60 min required. & \\
\hline & $\begin{array}{l}\text { c) Cerium (IV) } \\
\text { sulphate }\end{array}$ & & 540 & $0.05-300$ & & FIA assembly required & \\
\hline \multirow[t]{2}{*}{2.} & a) $\mathrm{KIO}_{3}$ & $\begin{array}{l}\text { Initial rate of } \\
\text { formation of radical } \\
\text { cation measured }\end{array}$ & 537 & Up to 4.0 & & $\begin{array}{c}\text { Scrupulous control of } \\
\text { experimental variables and } \\
\text { special equipment for kinetic } \\
\text { measurement required. }\end{array}$ & $\begin{array}{l}\text { Mohamed } \\
2008\end{array}$ \\
\hline & b) $\mathrm{KIO}_{3}$ & $\begin{array}{l}\text { Maximum } \\
\text { absorbance } \\
\text { measured }\end{array}$ & 537 & Up to 7.0 & & & \\
\hline \multirow[t]{3}{*}{3.} & a) NBS & $\begin{array}{l}\text { Radical cation } \\
\text { measured }\end{array}$ & 532 & $\begin{array}{c}10-120 \\
\left(\varepsilon=4.2 \times 10^{4}\right)\end{array}$ & 7.0 & $\begin{array}{l}\text { Uses } 1: 1 \text { miture of } \mathrm{H}_{2} \mathrm{SO}_{4} \text { and } \\
\mathrm{H}_{3} \mathrm{PO}_{4} \text { as the reaction medium, } \\
\text { colour stable for only } 30 \mathrm{~s} \text {. }\end{array}$ & $\begin{array}{l}\text { Krebs } \\
\text { et al., } \\
2006\end{array}$ \\
\hline & $\begin{array}{l}\text { b) NBS- } \\
\text { Celestine blue }\end{array}$ & $\begin{array}{l}\text { Unbleached dye } \\
\text { colour measured }\end{array}$ & 538 & $\begin{array}{c}0.5-6.0 \\
\left(\varepsilon=6.41 \times 10^{4}\right)\end{array}$ & 0.30 & High acidic conditions required & \\
\hline & $\begin{array}{l}\text { c) Cerium(IV)- } \\
\text { Celestine blue }\end{array}$ & & & $\begin{array}{c}0.6-3.0 \\
\left(\varepsilon=1.48 \times 10^{5}\right)\end{array}$ & 0.37 & & \\
\hline \multirow[t]{2}{*}{4.} & $\begin{array}{c}\text { a) } \mathrm{KMnO}_{4} \\
\text { (acid medium) }\end{array}$ & $\begin{array}{l}\text { Unreacted } \\
\mathrm{KMnO}_{4} \\
\text { measured }\end{array}$ & 550 & $\begin{array}{c}2.0-20.0 \\
\left(\varepsilon=1.34 \times 10^{4}\right)\end{array}$ & 1.13 & $\begin{array}{l}\text { Mild acidic/alkaline conditions } \\
\text { used; stable colour measured, } \\
\text { wide linear dynamic ranges } \\
\text { and fairly sensitive, simple } \\
\text { instrument employed. }\end{array}$ & $\begin{array}{l}\text { Present } \\
\text { work }\end{array}$ \\
\hline & $\begin{array}{l}\text { b) } \mathrm{KMnO}_{4}^{-} \\
\text {Alkaline } \\
\text { medium }\end{array}$ & $\begin{array}{l}\text { Bluish-green } \\
\text { manganate } \\
\text { measured. }\end{array}$ & 610 & $\begin{array}{c}1.0-10.0 \\
\left(\varepsilon=2.54 \times 10^{4}\right)\end{array}$ & 0.48 & & \\
\hline
\end{tabular}

\section{Sulphuric acid (0.1 and $2 \mathrm{M})$}

Concentrated acid (S.D. Fine Chem, Mumbai, India, sp. gr. 1.84) was appropriately diluted with water to get the required concentrations.

\section{Sodium hydroxide (1 M)}

Prepared by dissolving $4 \mathrm{~g}$ of the chemical (Merck, Mumbai, India) in $100 \mathrm{~mL}$ of water.

\section{Standard OLP solution}

Pharmaceutical grade OLP certified to be $99.85 \%$ pure was kindly provided by Cipla India Ltd., Mumbai, India; and was used as received. A $500 \mu \mathrm{g} \mathrm{mL} L^{-1}$ stock standard solution was prepared by dissolving accurately weighed $50 \mathrm{mg}$ of pure OLP in $0.1 \mathrm{M} \mathrm{H}_{2} \mathrm{SO}_{4}$ and diluting to the mark in a $100 \mathrm{~mL}$ calibrated flask with the same acid. It was subsequently diluted to $50 \mu \mathrm{g} \mathrm{mL} \mathrm{m}^{-1}$ OLP for method $\mathrm{A}$. Twenty $\mathrm{mg}$ of OLP were weighed separately and dissolved in $5 \mathrm{~mL}$ of $0.5 \mathrm{M}$ acetic acid and diluted to $100 \mathrm{~mL}$ in a calibrated flask with water. The solution was then diluted with water to get a working concentration of $20 \mu \mathrm{g} \mathrm{mL}^{-1}$ for use in method B.

\section{Tablets}

Three brands of tablets claimed to contain 2.5, 5.0 and $20 \mathrm{mg}$ OLP per tablet were purchased from local market for investigation. 


\section{Procedure}

\section{Method A}

Aliquots of standard OLP solution $\left(50 \mu \mathrm{g} \mathrm{mL}^{-1}\right)$ in the range $0.0-4.0 \mathrm{~mL}$ were accurately measured and transferred to a series of $10 \mathrm{~mL}$ calibrated flasks and the volume was adjusted to $4.0 \mathrm{~mL}$ with $0.1 \mathrm{M} \mathrm{H}_{2} \mathrm{SO}_{4}$. Two $\mathrm{mL}$ of $2 \mathrm{M} \mathrm{H}_{2} \mathrm{SO}_{4}$ were added to each flask followed by $1 \mathrm{~mL}$ of $600 \mu \mathrm{g} \mathrm{mL}^{-1} \mathrm{KMnO}_{4}$ solution. The content was mixed and the flasks were let stand for $15 \mathrm{~min}$ before diluting to the mark with water. The absorbance of each solution was measured at $550 \mathrm{~nm}$ against a reagent blank.

\section{Method B}

Known volumes of standard OLP solution $(0.0$, $1.0, \ldots . .5 .0 \mathrm{~mL}$ ) were accurately delivered into a series of $10 \mathrm{~mL}$ calibrated flasks and the volumes were adjusted to $5.0 \mathrm{~mL}$ with water. To each flask were added $1 \mathrm{~mL}$ each of $1 \mathrm{M} \mathrm{NaOH}$ and $0.2 \% \mathrm{KMnO}_{4}$ solutions. The content was mixed well and flasks were allowed to stand for $15 \mathrm{~min}$ with occasional shaking. Then, the volume was made up to the mark with water and absorbance measured at $610 \mathrm{~nm}$ against a reagent blank.

Calibration graphs were prepared by plotting either the decreasing absorbance values in method A or increasing absorbance values in method B versus concentrations of OLP. The unknown concentration was read from the respective calibration graph or deduced from the regression equation desired using the Beer's law data.

\section{Procedure for tablets}

Twenty tablets were weighed accurately and pulverized. A quantity of the powder containing $20 \mathrm{mg}$ of OLP was accurately weighed into a $100 \mathrm{~mL}$ calibrated flask, added $60 \mathrm{~mL}$ of $0.1 \mathrm{M} \mathrm{H}_{2} \mathrm{SO}_{4}$ and shaken for $20 \mathrm{~min}$. Then, the volume was diluted to the mark with $0.1 \mathrm{M} \mathrm{H}_{2} \mathrm{SO}_{4}$, mixed and filtered using a Whatman № 42 filter paper. First $10 \mathrm{~mL}$ of the filtrate were discarded and a suitable aliquot of the subsequent portion $\left(200 \mu \mathrm{g} \mathrm{mL}^{-1}\right.$ in OLP) was diluted with $0.1 \mathrm{M} \mathrm{H}_{2} \mathrm{SO}_{4}$ to obtain $50 \mu \mathrm{g} \mathrm{mL}^{-1}$ solution and the analysis was completed using the procedure described earlier (method A). However, for method B, a portion of the tablet powder equivalent to $20 \mathrm{mg}$ of OLP was accurately weighed into a $100 \mathrm{~mL}$ beaker. The powder was extracted with three $10 \mathrm{~mL}$ portions of chloroform and each time the extract was filtered with a Whatman № 42 filter paper. The filtrate was collected in $100 \mathrm{~mL}$ calibrated flask, chloroform was evaporated over a water bath and the residue was dissolved in $5 \mathrm{~mL} 0.5 \mathrm{M}$ acetic acid and the solution was diluted to the mark with water. The solution was appropriately diluted before applying the procedure for the assay of drug content.

\section{Placebo for analysis}

A placebo blank of the composition: starch $(10 \mathrm{mg})$, acacia (15 mg), hydroxyl cellulose ( $10 \mathrm{mg}$ ), sodium citrate $(10 \mathrm{mg})$, talc $(20 \mathrm{mg})$, magnesium stearate $(15 \mathrm{mg})$ and sodium alginate $(10 \mathrm{mg})$ was made and its solution was prepared as described under 'tablets', and then subjected to analysis.

\section{RESULTS AND DISCUSSION}

The proposed methods are based on the redox reaction between permanganate and OLP in acid (method A) or in alkali (method B) medium. In method A, a known excess of $\mathrm{KMnO}_{4}$ was added to OLP in $\mathrm{H}_{2} \mathrm{SO}_{4}$ medium followed by the determination of the residual oxidant by measuring its absorbance at $550 \mathrm{~nm}$. The decrease in absorbance at $550 \mathrm{~nm}$ with respect to the reagent blank was taken as the measure of OLP concentration. In method B, $\mathrm{K}_{2} \mathrm{MnO}_{4}$ resulting from the reduction of $\mathrm{KMnO}_{4}$ by OLP in $\mathrm{NaOH}$ medium was measured at $610 \mathrm{~nm}$ and related to OLP concentration. The possible reaction scheme of both the methods is given in Scheme 1 and Scheme 2.

\section{Method development: Optimization of experimental variables}

\section{Method A}

Preliminary experiments were performed to determine the permanganate concentration which would give a reasonable maximum absorbance at $550 \mathrm{~nm}$ and in $\mathrm{H}_{2} \mathrm{SO}_{4}$ medium; and this was found to be $60 \mu \mathrm{g} \mathrm{mL}^{-1}$ (0.811 absorbance unit). Hence, different concentrations of OLP were reacted with $1 \mathrm{~mL}$ of $600 \mu \mathrm{g} \mathrm{mL}^{-1} \mathrm{KMnO}_{4}$ in $\mathrm{H}_{2} \mathrm{SO}_{4}$ medium, and after elapsed the contact time, the absorbance of the residual permanganate was measured and related to OLP concentration.

When a fixed concentration of $\mathrm{KMnO}_{4}\left(60 \mu \mathrm{g} \mathrm{mL}^{-1}\right)$ was reacted with varying concentrations of OLP, the former was consumed in proportion to OLP concentration and there occurred a concomitant fall in the concentration of $\mathrm{KMnO}_{4}$ as shown by the decreasing absorbance values at $550 \mathrm{~nm}$ with increase in the OLP concentration. This is depicted in Figure. 2. This facilitated the evaluation of the linear range over which the method is applicable to the determination of OLP.

Since oxidation reactions with permanganate are usually performed in $\mathrm{H}_{2} \mathrm{SO}_{4}$ medium (Basset et al., 1978), 


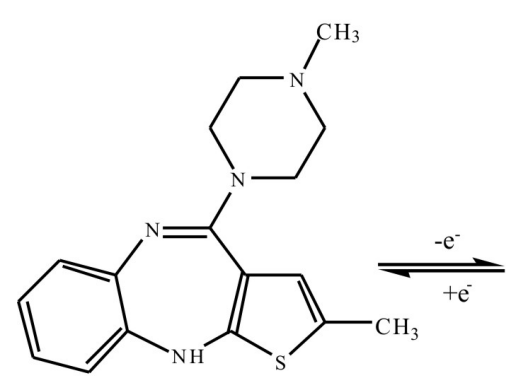<smiles>Cc1cc2c(s1)Nc1ccccc1N=C2N1CCN(C)CC1</smiles><smiles>Cc1cc2c(n1C=O)Nc1ccccc1N=C2N1CCN(C)CC1</smiles>

a. Oxidation mechanism for OLP with permanganate.

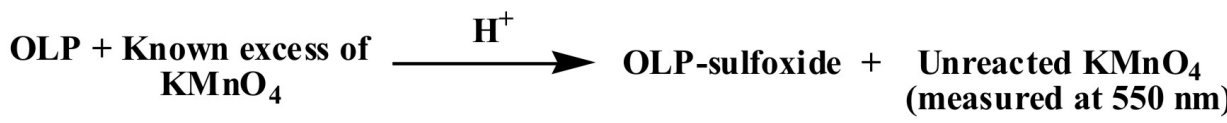

b. Reaction scheme basing the assay in method A.

Scheme 1 - Method A. Reaction scheme.

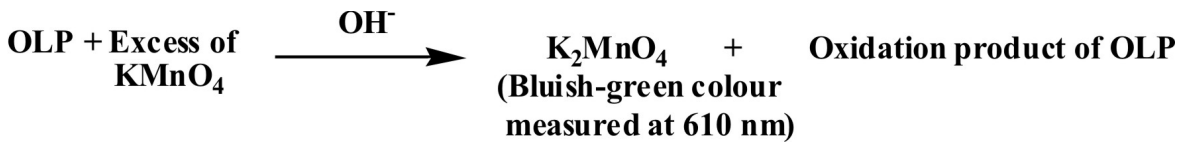

Scheme 2 - Method B. Reaction scheme.

the reaction of the oxidant with the drug was carried out in $\mathrm{H}_{2} \mathrm{SO}_{4}$ medium. Experiments were performed with $\mathrm{H}_{2} \mathrm{SO}_{4}$ concentrations in the range $0.5-1.5 \mathrm{M}$ and it was found that maximum and constant absorbance readings were obtained in the range studied (Figure 3a). Hence, $2 \mathrm{~mL}$ of $2 \mathrm{M} \mathrm{H}_{2} \mathrm{SO}_{4}$ in a total volume of $\sim 7 \mathrm{~mL}$ was fixed as the optimum. The reaction time selected for the recommended method was fixed by carrying out the experiment using $10 \mu \mathrm{g} \mathrm{mL}^{-1}$ OLP. Maximum absorbance was obtained in $15 \mathrm{~min}$ and it remained constant for the next $45 \mathrm{~min}$ (Figure $3 b$ ) at room temperature.

\section{Method B}

This method is based on the reduction of permanganate to manganate by OLP in the presence of $\mathrm{NaOH}$,

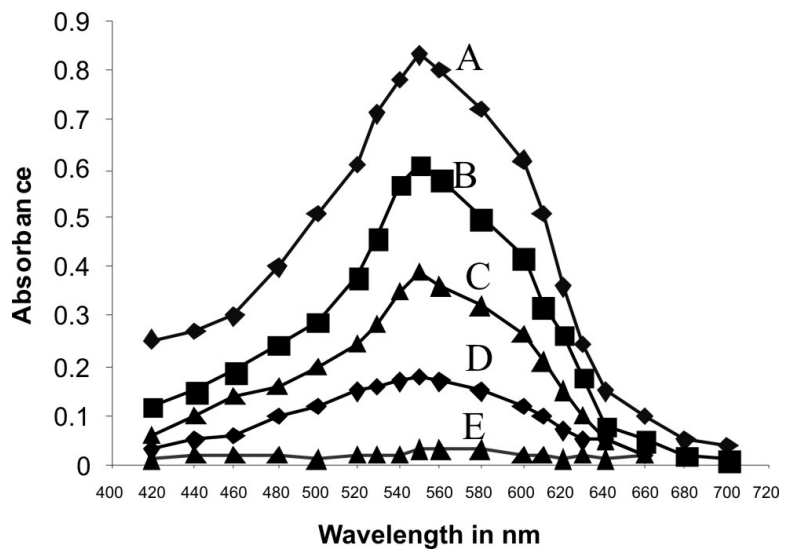

FIGURE 2 - Effect of OLP concentration on the absorbance of $60 \mu \mathrm{g} \mathrm{mL}^{-1} \mathrm{KMnO}_{4}$ (A.0.0; B.5.0; C.10.0; D.15.0 and E. $\left.20 \mu \mathrm{g} \mathrm{mL} \mathrm{mL}^{-1} \mathrm{OLP}\right)$. 


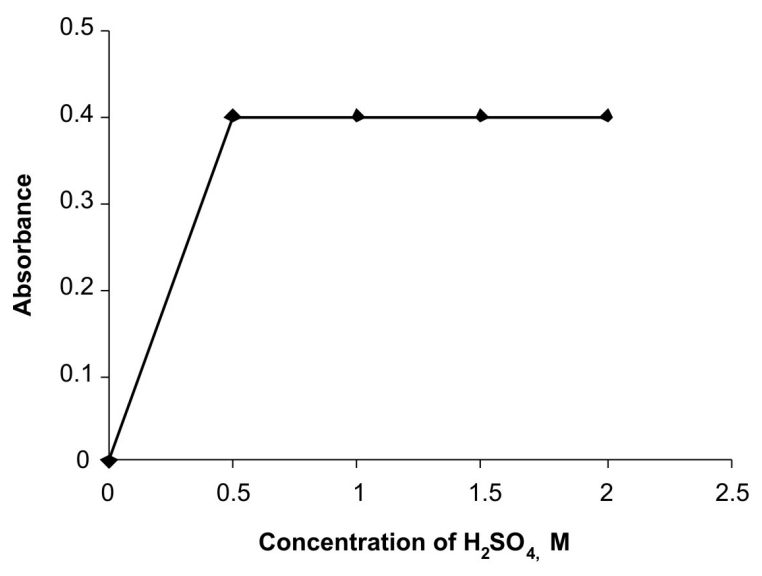

(a)

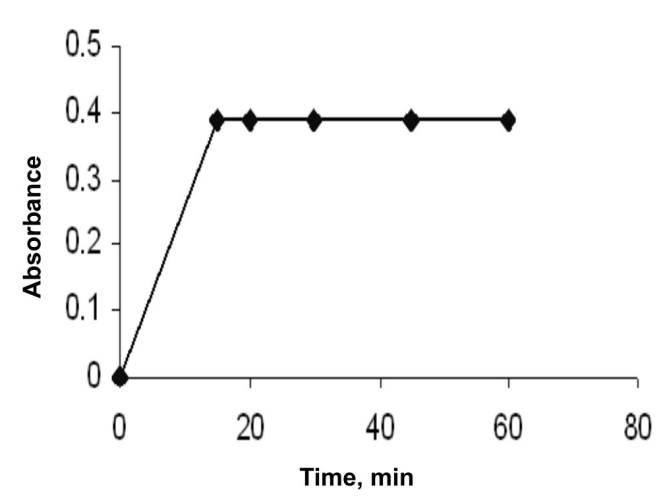

(b)

FIGURE 3 - Effect of $\mathrm{H}_{2} \mathrm{SO}_{4}$ concentration and reaction time (method A). (a). Effect of $\mathrm{H}_{2} \mathrm{SO}_{4}$ concentration $\left(10 \mu \mathrm{g} \mathrm{mL} \mathrm{LLP}^{-1} \mathrm{OLP}\right)$. (b)..Effect of reaction time and stability of the coloured species.

thereby producing the reduced species - the bluish-green colored chromogen (Mann, Sounders, 1974; Sharma, 1994) having the absorption maximum at $610 \mathrm{~nm}$ (Figure 4). The formation of the colored product and the sensitivity of the reaction were found to be influenced by the alkali and permanganate concentrations. Maximum and constant absorbance readings were observed when an overall $\mathrm{NaOH}$ concentration of $0.06-0.5 \mathrm{M}$ was maintained at a drug concentration of $6 \mu \mathrm{g} \mathrm{mL}^{-1}$. Two $\mathrm{mL}$ of $2 \mathrm{M} \mathrm{NaOH}$ in a total volume of $7 \mathrm{~mL}$ were hence used for the redox reaction (Figure. 5a). The reaction was somewhat rapid compared to method $\mathrm{A}$, taking $10 \mathrm{~min}$ for completion, and the bluish-green manganate color was stable for $40 \mathrm{~min}$ thereafter (Figure 5b). When a separate experiment was conducted to study the permanganate concentration, it was found that maximum absorbance associated with a minimum blank reading was obtained when $1 \mathrm{~mL}$ of $0.2 \% \mathrm{KMnO}_{4}$ in a total volume of $10 \mathrm{~mL}$ was used. Higher concentrations of permanganate, no doubt, resulted in increased sensitivity but the blank absorbance simultaneously showed an increasing trend.

\section{Method validation}

- Linearity, sensitivity, limits of detection and quantification

Calibration graphs were constructed from nine and six points covering the concentration ranges 2.020.0 and $1-10 \mu \mathrm{g} \mathrm{mL}^{-1}$ for method $\mathrm{A}$ and method $\mathrm{B}$, respectively (Figure 6). In method A, Beer's law was obeyed in the inverse manner. Regression analysis of the Beer's law data indicated a linear relationship be-

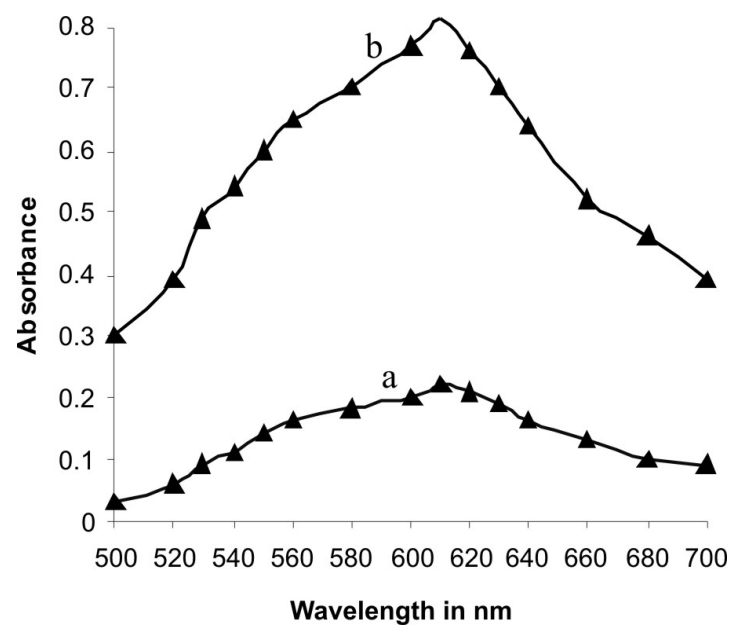

FIGURE 4 - Absorption spectra for method B (a. reagent blank; b. coloured species produced for $8 \mu \mathrm{g} \mathrm{mL} \mathrm{m}^{-1} \mathrm{OLP}$ ).

tween absorbance and concentration (Table II), which is corroborated by high values (close to unity) of the correlation coefficients. The small values of the variance speak about the negligible scattering of the calibration data points around the line of regressions for both the proposed procedures. The significance of correlation coefficients was evaluated by calculating the t-values using the following formula (Miller, Miller, 2000):

$t=\frac{|r| \sqrt{n-2}}{\sqrt{1-r^{2}}}$

The calculated values were found to be 30.26 and 48.45 for method A and method B, respectively. Thus, 


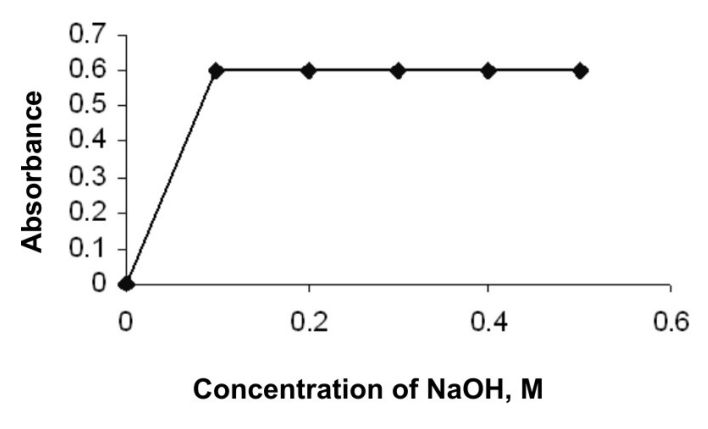

(a)

FIGURE 5 - Effect of $\mathrm{NaOH}$ concentration and standing time. (a). Effect of $\mathrm{NaOH}$ concentration $\left(6 \mu \mathrm{g} \mathrm{mL}^{-1} \mathrm{OLP}\right)$. (b). Effect of reaction time and stability of the coloured species.

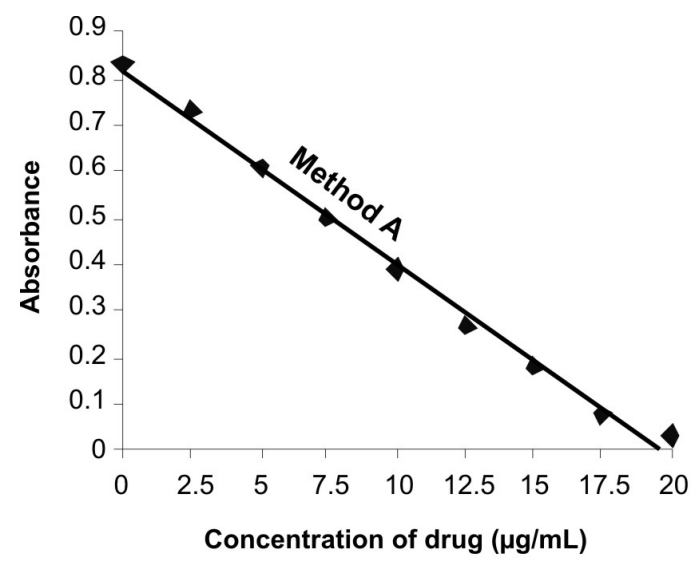

(a)

FIGURE 6 - Calibration curves for method A and method B.

it can be concluded that there is significant relationship between the concentration of OLP and the parameters used in the development of regression equations.

The calculated molar absorptivity and Sandell sensitivity (Zavis et al., 1976) values are summarized in Table II. The limits of detection (LOD) and quantification (LOQ), calculated according to the ICH (ICH guidelines 1996) guidelines using the formulae:

$\mathrm{LOD}=3.3 \mathrm{~S} / \mathrm{b}$ and $\mathrm{LOQ}=10 \mathrm{~S} / \mathrm{b}$, (where $\mathrm{S}$ is the standard deviation of seven blank absorbance values, and b is the slope of the calibration plot) are also summarized in Table II. The high values of $\varepsilon$ and low values of Sandell sensitivity and LOD indicate the high sensitivity of the proposed methods. The reaction stoichiometry for method B was determined by the Job's method of continuous variations and was found to be 1:4 (OLP: $\left.\mathrm{KMnO}_{4}\right)$.

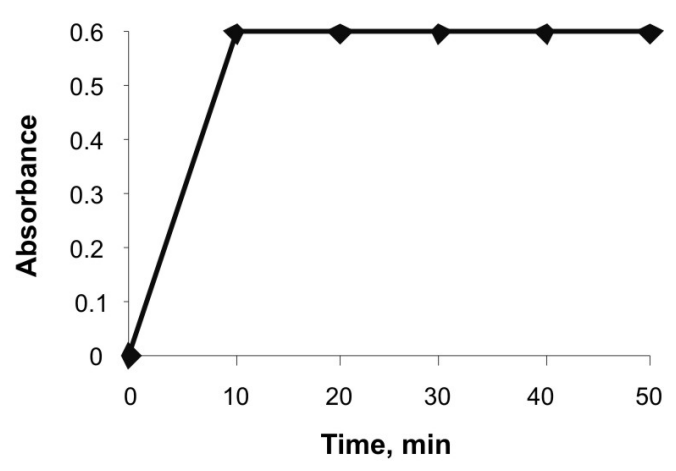

(b)

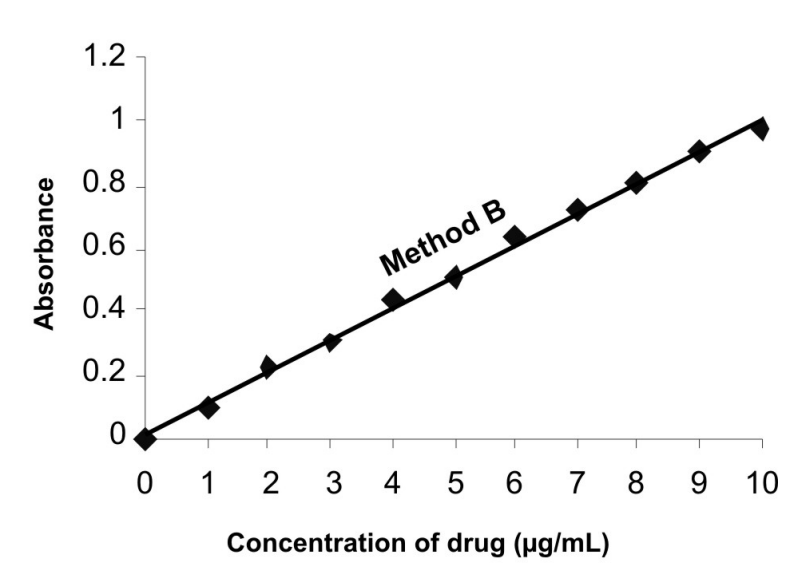

(b)

- Precision and accuracy

The assays described under "general procedures" were repeated seven times within the day to determine the repeatability (intra-day precision) and six times on different days to determine the intermediate precision (inter-day precision) of the methods. These assays were performed for three levels of analyte. The results of this study are summarized in Table III. The percentage relative standard deviation (\%RSD) values were $<2 \%$ (intra-day) and $<3 \%$ (inter-day) indicating high precision of the methods. The accuracy of the methods was determined by the percent mean deviation from known concentration, bias \% $=[$ (Concentration found - known concentration $) \mathrm{x}$ 100/known concentration].

Bias was calculated at each concentration and these results are also presented in Table III. 
TABLE II - Sensitivity and regression parameters

\begin{tabular}{|c|c|c|}
\hline Parameter & Method A & Method B \\
\hline$\lambda_{\max }, \mathrm{nm}$ & 550 & 610 \\
\hline Color stability, min. & 45 & 40 \\
\hline Linear range, $\mu \mathrm{g} \mathrm{mL} \mathrm{m}^{-1}$ & $2.0-20.0$ & $1.0-10.0$ \\
\hline $\begin{array}{l}\text { Molar absorptivity }(\varepsilon) \\
\mathrm{L} \mathrm{mol}^{-1} \mathrm{~cm}^{-1}\end{array}$ & $1.34 \times 10^{4}$ & $2.54 \times 10^{4}$ \\
\hline Sandell sensitivity*, $\mu \mathrm{g} \mathrm{cm}^{-2}$ & 0.0233 & 0.0123 \\
\hline $\begin{array}{l}\text { Limit of detection (LOD), } \\
\mu \mathrm{g} \mathrm{mL}^{-1}\end{array}$ & 0.37 & 0.16 \\
\hline $\begin{array}{l}\text { Limit of quantification (LOQ), } \\
\mu \mathrm{g} \mathrm{mL}^{-1}\end{array}$ & 1.13 & 0.48 \\
\hline \multicolumn{3}{|l|}{ Regression equation, $\mathrm{Y}^{* *}$} \\
\hline Intercept (a) & 0.8111 & 0.0310 \\
\hline Slope (b) & -0.0411 & 0.0965 \\
\hline Standard deviation of a $\left(\mathrm{S}_{\mathrm{a}}\right)$ & 0.0998 & 0.0998 \\
\hline$\pm \mathrm{tS}_{\mathrm{a}} / \sqrt{\mathrm{n}}$ & 0.077 & 0.071 \\
\hline Standard deviation of $b\left(S_{b}\right)$ & 0.0052 & 0.0111 \\
\hline$\pm \mathrm{tS}_{\mathrm{b}} / \sqrt{\mathrm{n}}$ & 0.004 & 0.008 \\
\hline Variance $\left(\mathrm{S}_{\mathrm{a}}^{2}\right)$ & $9.96 \times 10^{-3}$ & $9.96 \times 10^{-3}$ \\
\hline Regression coefficient (r) & -0.9962 & 0.9983 \\
\hline
\end{tabular}

*Limit of determination as the weight in $\mu \mathrm{g}$ per $\mathrm{mL}$ of solution, which corresponds to an

absorbance of $\mathrm{A}=0.001$ measured in a cuvette of crosssectional area $1 \mathrm{~cm}^{2}$ and $\mathrm{l}=1 \mathrm{~cm} .{ }^{* *} \mathrm{Y}=\mathrm{a}+\mathrm{bX}$, Where $\mathrm{Y}$ is the absorbance, $\mathrm{X}$ is concentration in $\mu \mathrm{g} \mathrm{mL}^{-1}$, $\mathrm{a}$ is intercept, $\mathrm{b}$ is slope, $\pm \mathrm{tS}_{\mathrm{a}} / \sqrt{ } \mathrm{n}=$ confidence limit for intercept, $\pm \mathrm{tS}_{\mathrm{b}} / \sqrt{\mathrm{n}}=$ confidence limit for slope.

\section{- Selectivity}

A systematic study was performed to determine the effect of matrix by analyzing the placebo blank and synthetic mixture containing OLP. A placebo blank of the composition described earlier was prepared and analyzed. The absorbance of the placebo solution in each case was almost equal to the intercept of the calibration graph, which revealed no interference. To assess the role of the inactive ingredients on the assay of OLP, a synthetic mixture was separately prepared by adding 20 $\mathrm{mg}$ of OLP to the placebo mentioned above. The drug was extracted and solution prepared as described under the general procedure for tablets. The solution after appropriate dilution were analyzed following the recommended procedures. The absorbance resulting from $10 \mu \mathrm{g}$ $\mathrm{mL}^{-1}(\operatorname{method} \mathrm{A})$ and $6 \mu \mathrm{g} \mathrm{mL}^{-1}(\operatorname{method} \mathrm{B})$ were nearly the same as those obtained for pure OLP solutions of identical concentrations. This unequivocally demonstrated the non-interference of the inactive ingredients in the assay of OLP. Further, the slopes of the calibration plots prepared from the synthetic mixture solutions were about the same as those prepared from pure drug solutions. In method B (alkaline medium) a strong interference was noticed from some tablet excipients causing erratic results. To overcome this interference, after several trials, it was found that OLP in the synthetic mixture or the tablet should be extracted with chloroform, before applying the method following the steps involved in the assay procedure.

\section{Robustness and ruggedness}

To determine the robustness of the methods, two experimental variables, acid/alkaline concentration and reaction time, were altered deliberately in small increments. Intermediate precision expressed as \%RSD was calculated and found to be $<1 \%$. Method ruggedness was demonstrated having the analysis done by four analysts, and also by a single analyst performing analysis on three different instruments in the same laboratory. Intermediate precision values in both instances were in the range 0.85 $3.06 \%$ indicating acceptable ruggedness. These results are summarized in Table IV

TABLE III - Evaluation of accuracy and precision

\begin{tabular}{|c|c|c|c|c|c|c|c|}
\hline \multirow[b]{2}{*}{ Method } & \multirow{2}{*}{$\begin{array}{l}\text { OLP taken, } \\
\mu \mathrm{g} \mathrm{mL}^{-1}\end{array}$} & \multicolumn{3}{|c|}{ Intra-day accuracy and precision $(\mathrm{n}=7)$} & \multicolumn{3}{|c|}{ Inter-day accuracy and precision $(\mathrm{n}=6)$} \\
\hline & & $\begin{array}{l}\text { OLP found } \mu \mathrm{g} \\
\mathrm{mL}^{-1} \pm \mathrm{CL}\end{array}$ & $\% \mathrm{RE}$ & $\%$ RSD & $\begin{array}{l}\text { OLP found } \mu \mathrm{g} \\
\mathrm{mL}^{-1} \pm \mathrm{CL}\end{array}$ & $\% \mathrm{RE}$ & $\% \mathrm{RSD}$ \\
\hline \multirow{3}{*}{ A } & 5.00 & $4.92 \pm 0.08$ & 1.60 & 1.76 & $4.89 \pm 0.12$ & 2.20 & 2.66 \\
\hline & 10.0 & $10.2 \pm 0.11$ & 2.00 & 1.13 & $10.02 \pm 0.22$ & 0.20 & 2.34 \\
\hline & 15.0 & $14.8 \pm 0.09$ & 1.33 & 0.67 & $15.28 \pm 0.28$ & 1.87 & 1.97 \\
\hline \multirow{3}{*}{ B } & 2.00 & $2.02 \pm 0.01$ & 1.00 & 0.51 & $2.03 \pm 0.02$ & 1.50 & 1.24 \\
\hline & 4.00 & $4.05 \pm 0.06$ & 1.25 & 1.50 & $3.94 \pm 0.09$ & 1.50 & 2.37 \\
\hline & 6.00 & $5.90 \pm 0.09$ & 1.67 & 1.68 & $6.12 \pm 0.12$ & 2.00 & 2.08 \\
\hline
\end{tabular}

\%RE. Percent relative error, \%RSD. relative standard deviation and CL. Confidence limits were calculated from: $C L= \pm t S / \sqrt{ }$. $(\mathrm{t}=2.44$ for six degrees of freedom at the $95 \%$ confidence level; $\mathrm{S}=$ standard deviation and $\mathrm{n}=$ number of measurements). 
TABLE IV - Method robustness and ruggedness expressed as intermediate precision (\% RSD)

\begin{tabular}{|c|c|c|c|c|c|}
\hline \multirow{3}{*}{ Method } & \multirow{3}{*}{$\begin{array}{l}\text { OLP taken } \\
\mu \mathrm{g} / \mathrm{mL}^{-1}\end{array}$} & \multicolumn{2}{|c|}{ Robustness } & \multicolumn{2}{|c|}{ Ruggedness } \\
\hline & & \multicolumn{2}{|c|}{ Parameter altered } & \multirow{2}{*}{$\begin{array}{l}\text { Inter-Analysts } \\
\text { (\% RSD) }\end{array}$} & \multirow{2}{*}{$\begin{array}{c}\text { Inter-instruments } \\
(\% \text { RSD })\end{array}$} \\
\hline & & Reaction time* & $\begin{array}{l}\mathrm{H}_{2} \mathrm{SO}_{4} / \mathrm{NaOH} \\
\text { concentration }^{* *}\end{array}$ & & \\
\hline \multirow[b]{2}{*}{ A } & 5.00 & 0.76 & 0.66 & 1.04 & 2.74 \\
\hline & 10.0 & 0.82 & 0.74 & 0.86 & 3.05 \\
\hline \multirow[t]{2}{*}{ B } & 4.00 & 0.83 & 0.48 & 0.92 & 3.16 \\
\hline & 6.00 & 0.78 & 0.78 & 0.85 & 2.58 \\
\hline
\end{tabular}

*In method A, the reaction times were 13,15 and $17 \mathrm{~min}$, and the same were 8,10 and 12 min in method B. ${ }^{* *} \mathrm{In}_{\text {method } \mathrm{A}, \mathrm{H}_{2} \mathrm{SO}_{4}}$ concentrations were $0.5,0.6$ and $0.7 \mathrm{M}$, and $\mathrm{NaOH}$ concentrations in method $\mathrm{B}$ were $0.1,0.2$ and $0.3 \mathrm{M}$.

\section{Application}

The proposed methods are applied for the quantification of OLP in commercial tablets. The results were compared with those obtained using a published non-aqueous titrimetric method (Firdous et al., 2005). Statistical analysis of the results did not detect any significant difference between the performance of the proposed methods and reference titrimetric method, with respect to accuracy and precision as revealed by the Student's t-value and variance ratio F-value (Inczedy et al., 1998). The results of assay are given in Table $\mathrm{V}$.

\section{Recovery study}

To further assess the accuracy of the methods, recovery experiments were performed by applying the standard-addition technique. The recovery was assessed by determining the agreement between the measured standard concentration and added known concentration to the sample. The test was done by spiking the pre-analyzed tablet powder with pure OLP at three different levels (50, 100 and $150 \%$ ) of the content present in the tablet powder (taken), and the total was found by the proposed methods. Each test was repeated three times. In all the cases, the recovery percentage values ranged between 99.4 and $104.1 \%$, with relative standard deviation in the range 1.35 $1.78 \%$. Closeness of the results to $100 \%$ showed the fairly good accuracy of the methods (Table VI).

\section{CONCLUSIONS}

The methods proposed herein, based on the use of spectrophotometry with permanganate, can reliably determine olanzapine in pharmaceuticals, with good accuracy and precision. Furthermore, the methods are more sensitive, as compared to many published spectrophotometric metho-

TABLE V - Results of analysis of tablets by the proposed methods and statistical comparison of the results with the reference method.

\begin{tabular}{|c|c|c|c|c|c|c|}
\hline \multirow{2}{*}{$\begin{array}{l}\text { Tablet brand } \\
\text { name }{ }^{\psi}\end{array}$} & \multirow{2}{*}{$\begin{array}{l}\text { Nominal amount } \\
(\mathrm{mg} / \text { tablet })\end{array}$} & \multicolumn{2}{|c|}{ Found $(\mathrm{mg} \pm \mathrm{CL})$} & \multicolumn{3}{|c|}{ Found $^{*}$ (Percent of label claim \pm SD) } \\
\hline & & Method A & Method B & $\begin{array}{l}\text { Reference } \\
\text { method }\end{array}$ & Method A & Method B \\
\hline Olimelt-2.5 ${ }^{\mathrm{a}}$ & 2.5 & $2.60 \pm 0.04$ & $2.57 \pm 0.03$ & $103.6 \pm 0.52$ & $\begin{array}{c}104.1 \pm 1.26 \\
\mathbf{t}=0.89 \\
\mathbf{F}=5.87\end{array}$ & $\begin{array}{c}102.8 \pm 0.96 \\
\mathbf{t}=1.71 \\
\mathbf{F}=3.41\end{array}$ \\
\hline Oleanz- $5^{\mathrm{b}}$ & 5.0 & $4.94 \pm 0.08$ & $4.90 \pm 0.07$ & $97.48 \pm 0.75$ & $\begin{array}{c}98.73 \pm 1.35 \\
\mathbf{t}=1.88 \\
\mathbf{F}=3.24\end{array}$ & $\begin{array}{c}98.04 \pm 1.08 \\
\mathbf{t}=0.97 \\
\mathbf{F}=2.07\end{array}$ \\
\hline Oleanz-20 $0^{c}$ & 20.0 & $19.8 \pm 0.27$ & $20.0 \pm 0.33$ & $98.54 \pm 0.68$ & $\begin{array}{c}99.14 \pm 1.09 \\
\mathbf{t}=1.07 \\
\mathbf{F}=2.57\end{array}$ & $\begin{array}{c}100.1 \pm 1.35 \\
\mathbf{t}=2.43 \\
\mathbf{F}=3.94\end{array}$ \\
\hline
\end{tabular}

${ }^{*}$ Mean value of 5 determination. ${ }^{\psi}$ Marketed by : ${ }^{\mathrm{a}}$ Ranbaxy Laboratories Ltd (Solus), ${ }^{\mathrm{b}}$ Cipla India Pvt Ltd (Mumbai),

'SunPharmaceuticals Industries Ltd, Mumbai, India. 
TABLE VI - Results of recovery study via standard-addition method

\begin{tabular}{|c|c|c|c|c|c|c|c|c|}
\hline \multirow[b]{2}{*}{$\begin{array}{l}\text { Tablet } \\
\text { studied }\end{array}$} & \multicolumn{4}{|c|}{ Method A } & \multicolumn{4}{|c|}{ Method B } \\
\hline & $\begin{array}{c}\text { OLP in tablet, } \\
\mu \mathrm{g} \mathrm{mL}^{-1}\end{array}$ & $\begin{array}{c}\text { Pure OLP } \\
\text { added, } \mu \mathrm{g} \\
\mathrm{mL}^{-1}\end{array}$ & $\begin{array}{l}\text { Total found, } \\
\mu \mathrm{g} \mathrm{mL}^{-1}\end{array}$ & $\begin{array}{c}\text { Pure OLP } \\
\text { recovered } \\
\left(\text { Percent } \pm \mathrm{SD}^{*}\right)\end{array}$ & $\begin{array}{l}\text { OLP in tablet, } \\
\mu \mathrm{g} \mathrm{mL}^{-1}\end{array}$ & $\begin{array}{c}\text { Pure OLP } \\
\text { added, } \mu \mathrm{g} \\
\mathrm{mL}^{-1}\end{array}$ & $\begin{array}{l}\text { Total found, } \\
\mu \mathrm{g} \mathrm{mL}^{-1}\end{array}$ & $\begin{array}{c}\text { Pure OLP } \\
\text { recovered } \\
\left(\text { Percent } \pm \mathrm{SD}^{*}\right)\end{array}$ \\
\hline \multirow{3}{*}{ Oleanz-20 } & 4.96 & 2.5 & 7.52 & $102.3 \pm 1.76$ & 3.0 & 1.5 & 4.49 & $99.47 \pm 1.46$ \\
\hline & 4.96 & 5.0 & 10.17 & $104.1 \pm 1.45$ & 3.0 & 3.0 & 6.10 & $103.3 \pm 1.78$ \\
\hline & 4.96 & 7.5 & 12.59 & $101.7 \pm 1.57$ & 3.0 & 4.5 & 7.56 & $101.4 \pm 1.35$ \\
\hline
\end{tabular}

*Mean value of three determinations.

ds (Jasinska, Nalewajko., 2004; Mohamed., 2008; Krebs et al., 2006) and also some HPLC methods (Olesen et al., 1998; Harald et al., 2001; Concetta et al., 2006; Dusci et al., 2002; Olesen et al., 2001; Raggi et al., 2001; Raggi et al., 2000; Shah et al., 2007; Reddy et al., 2007; Xuejun et al., 2004). The methods are simpler as compared to published methods (Jasinska, Nalewajko, 2004; Mohamed, 2008; Krebs et al., 2006) with respect to experimental conditions, instrumental setup and the stability of the measured species. An all important advantage is the cost-effectiveness, since analysis can be performed with an inexpensive instrument as compared to methods (Jasinska, Nalewajko, 2004; Mohamed, 2008) which require expensive devices and/or reagents (Table I). The methods are rapid and allow the determination of the drug in tablets without any interference from the common tablet excipients. The limitation of method B (in alkaline medium) is that it cannot be applied directly to the tablets, and involves extraction of the drug into chloroform and evaporation of the organic solvent before other steps are applied for the assay.

\section{ACKNOWLEDGEMENTS}

Authors thank M/S. Cipla India Ltd., for gifting pure olanzapine. One of the authors (N.R.P) thanks the authorities of the University of Mysore, Mysore, India, for permission and facilities.

\section{REFERENCES}

ABDELLATEF, H. E. Kinetic spectrophotometric determination of tramadol hydrochloride in pharmaceutical formulation. $J$. Pharm. Biomed. Anal., v.29, n.5, p.835-842, 2002.

AL-GHANMAN S.M.; BELAL, F. Spectrophotometric determination of diloxanide furoate in its dosage forms. Il Farmaco, v.56, n.9, p.677-681, 2001.

AL-TAMRAH, S. A. Spectrophotometric determination of nicotine. Anal. Chim. Acta., v.379, n.1-2, p.75-80,1999.
BAO, J.Q.; POTTS, B.D. Quantitative determination of olanzapine in rat brain tissue by high-performance liquid chromatography with electrochemical detection. $J$. Chromatogr. B, v.752, n.1, p.61-67, 2001.

BASSET, J.; DENNEY, R.C.; JEFFREY, G.H.; MENDHAM, J. Vogel's textbook of quantitative chemical analysis. 5.ed. London: Longman Group Limited., 1978. p.368

BERNA, M.; ACKERMANN, B.; RUTERBORIES, K.; GLASS, S. Determination of olanzapine in human blood by liquid chromatography-tandem mass spectrometry. $J$. Chromatogr. B, v.767, n.1, p.163-168, 2002.

BOULTON, D.W.; MARKOWITZ, J.S.; DEVANE, C.L.; A high-performance liquid chromatography assay with ultraviolet detection for olanzapine in human plasma and urine. J. Chromatogr. B, v.759, n.2, p.319-323, 2001.

BRIGHT, H.A. Vogel text book of inorganic analysis including elementary instrumental analysis. 3.ed. London: Longman Group Limited, 1962. p.280.

CONCETTA, D.; GAETANA, M.; VINCENZA, S.; EDOARDO, $S$. Determination of olanzapine in human-plasma by reversed-phase high-performance liquid chromatography with ultraviolet detection. Ther. Drug Monit., v.28, n.3, p.388-393, 2006.

DUSCI, L. J.; HACKETT, L.P.; FELLOWS, L.M.; ILETT, K.F. Determination of olanzapine in plasma by highperformance liquid chromatography using ultraviolet absorbance detection. J. Chromatogr., B, v.773, n.2, p.191197, 2002.

FEDCHENKO, S.B. Determination of chloramphenicol in $0.25 \%$ solution. Farmatsiya (Moscow). v.33, n.1, p.68-69, 1984. 
FIRDOUS, S.; AMAN, T.; NISA, A. Determination of olanzapine by UV spectrophotometry and non-aqueous titration. J. Chem. Soc. Pak, v.27, n.2, p.163-167, 2005.

HARALD, W.; SEBASTIAN, H.; SABINE, M.; WERNER, K.; GODEHARD, K.; GERD, D.; CHROSTOPH, H. Simultaneous determination olanzapine, clozapine and demethylated metabolites in serum by online columnswitching high-performance liquid chromatography. J. Chromatogr, B, v.759, n.1, p.63-71, 2001.

INCZEDY, J.; LENGYEL, T.; URE, A.M. IUPAC Compendium of analytical nomenclature : definitive rules. Boston: Blackwell Science Inc., 1998. No pagination.

\section{INTERNATIONAL CONFERENCE ON HARMONIZATION} OF TECHNICAL REQUIREMENTS FOR REGISTRATION OF PHARMACEUTICALS FOR HUMAN USE. ICH Harmonised tripartite guideline. Validation of analytical procedures: Text and methodology Q2(R1). Complementary guideline on methodology. London: [s.n.], 1996. No pagination.

JASINSKA, A.; NALEWAJKO, E. Batch and flow-injection methods for the spectrophotometric determination of olanzapine. Anal. Chim. Acta, v.508, n.2, p.165-170, 2004.

KASPER, S.C.; MATTIUZ, E.L.; SWANSON, S.P.; CHIU, J.A.; JOHNSON, J.T.; GARNER C.O. Determination of olanzapine in human breast milk by high-performance liquid chromatography. J. Chromatogr. B, v.726, n.1-2, p.203-209, 1999.

K R E B S, A.; S T A R C Z E W S K A, B .; PUZANOWSHATARASIEWICZ, H.; SLEDZ, J. Spectrophotometric determination of olanzapine with N-bromosuccinimide and cerium(IV)sulphate. Anal. Sci., v.22, n.6, p.829-833, 2006.

KUCHARSKI, M.; SIKORSKA-TOMICKA, H. Potentiometric and amperometric determination of methyl thiouracil with potassium permanganate. Chem. Anal. (Warsaw), v.27, n.56. p.491-496, 1982.

MANN, F-G.; SOUNDERS, B. C. New impressions. 4.ed. Cambridge: Orient Longman, 1974. p.85.

MILLER, J.N.; MILLER, J.C. Statistics and chemometrics for analytical chemistry. 5.ed. New Jersey: Prentice-Hall, 2000. p.114.
MOHAMED, A.A. Kinetic and maximum-absorbance spectrophotometric methods for the determination of olanzapine. Monatsh. Chem., v.139, n.9, p.1005-1010, 2008.

MURUGESAN, A.; VENKAPPAYYA, D. New method for estimation of isoniazid. Curr. Sci., v.52, n.6, p.249-249, 1983.

OLESEN, O.V.; LINNET, K. Determination of olanzapine in serum by high-performance liquid chromatography using ultraviolet detection considering the easy oxidizability of the compound and the presence of other psychotropic drugs. J. Chromatogr. B, v.714, n.2, p.309-315, 1998.

OLESEN, O.V.; POULSEN, B.; LINNET, K. Fully automated online determination of olanzapine in serum for routine therapeutic drug monitoring. Ther. Drug Monit., v.23, n.1, p.51-55, 2001.

RAGGI, M.A.; CASAMENTI, G.; MANDRIOLI, R.; FANALI, S.; DE RONCHI, D.; VOLTERRA, V. Determination of the novel antipsychotic drug olanzapine in human plasma using HPLC with amperometric detection. Chromatographia, v.51, n.9-10, p.562-566, 2000.

RAGGI, M.A.; CASAMENTI, G.; MANDRIOLI, R.; IZZO, G.; KENNDLER, E.; Quantification of olanzapine in tablets by HPLC, CZE, derivative spectrometry and linear voltammetry. J. Pharm. Biomed. Anal., v.23, n.6, p.973981, 2000.

RAGGI, M. A.; CASAMENTI, G.; MANDRIOLI, R.; VOLTERRA, V. A sensitive high-performance liquid chromatographic method using electrochemical detection for the analysis of olanzapine and desmethylolanzapine in plasma of schizophrenic patients using a new solid-solid phase extraction procedure. J. Chromatogr. B, v.750, n.1, p.137-146, 2001.

RAGGI, M. A.; MANDRIOLI, R.; SABBIONI, C.; GHEDINI, N.; FANALI, S.; VOLTERRA, V. Determination of olanzapine and desmethylolanzapine in the plasma of schizophrenic patients by means of an improved HPLC method with amperometric detection. Chromatographia, v.54, n.3-4, p.203-207, 2001.

REDDY, M.N.; REDDY, V.P.N.; REDDY, P.J.C.; MURTHY, T.K.; SRINIVASA RAO, Y. Spectrophotometric determination of cefuroxime sodium in pharmaceutical dosage forms. Antiseptic., v.99, n.3, p.88-89, 2002. 
REDDY, B.V.; SURESH REDDY, K.V.N.; SREERAMULU, J.; KANUMULA, G.V.; Simultaneous determination of olanzapine and fluoxetine by HPLC. Chromatographia, v.66, n.1-2, p.111-114, 2007.

SABBIONI, C.; SARACINO, M. A.; MANDRIOLI, R.; ALBERS, L.; ONCOMPAGNI, G.; RAGGI, M. A. Rapid analysis of olanzapine and desmethylolanzapine in human plasma using high-performance liquid chromatography with coulometric detection. Anal. Chim. Acta, v.516, n.1-2, p.111-117, 2004.

SARACINO, M.A.; GANDOLFI, O.; DALL'OLIO, R.O.; ALBERS, L.; KENNDLER, E.; RAGGI M,.A. Determination of olanzapine in rat brain using liquid chromatography with coulometric detection and a rapid solid-phase extraction procedure. J. Chromatogr. A, v. 1122, n.1-2, p.21-27, 2006.

SARACINO, M. A.; KOUKOPOULOS, A.; SANI, G.; AMORE, M.; RAGGI, M.A. Simultaneous high-performance liquid chromatographic determination of olanzapine and lamotrigine in plasma of bipolar patients. Ther. Drug Monitor, v.29, n.6, p.773-780, 2007.

SASTRY, C.S.P.; VIJAYA, R.T.; SATYANARAYANA, A. Spectrophotometric determination of pentazocine in pharmaceutical formulations. Indian. J. Pharm. Sci., v.60, n.1, p.55-58, 1998.

SHAH, C.R.; SHAH, N.J.; SUAGIA, B.N.; PATEL, N.M. Simultaneous Assay of Olanzapine and Fluoxetine in Tablets by Column High-Performance Liquid Chromatography and High-Performance Thin-Layer Chromatography. J. AOAC, v.90, n.6, p.1573-1578, 2007.
SHARMA, B.K. Instrumental methods of analysis. 18.ed. Meerut: Goel Publishing Home, 1994. p.114.

SHEN, W.W. The metabolism of atypical antipsychotic drugs: an update. Ann. Clin. Psych., v.11, n.3, p.145-158, 1999.

STEPNAYUK, S.N.; BALAGORAZUMNYA, N.V. Permanganometric determination of amidopyrine in dosage forms. Farmatsiya (Moscow)., v.38, n.1, p.67-69,1989.

SUGANTHI, A.; SHIVAKUMAR, H.B.; VIJAYKUMAR, S.C.; RAVIMATHI, P.; RAVI, T.K.; Visible spectrophotometric determination of valdecoxib in tablet dosage forms. Indian J. Pharm. Sci., v.68, n.3, p.373-374, 2006.

TAMMILEHTO, S.A. Oxidation of chlorprothinene with potassium permanganate. J. Pharm. Pharmacol., v.32, n.7, p.524-524, 1980.

THIEME, D.; SACHES, H. Imporoved screening capabilities in forensic toxicology by application of LC-MS-MS. Anal. Chim. Acta, v.492, n.1-2, p.171-186, 2003.

TITIER, K.; BOUCHET, S.; PEHOURCQ, F.; MOORE, N.; MOLIMARD, M. High-performance liquid chromatographic method with diode array detection to identify and quantify atypical antipsychotics and haloperidol in plasma after overdose. J. Chromatogr. B, v.788, n.1, p.179-185, 2003.

XUEJUN, X.; ZHONGHUA, T. Determination of olanzapine and its tablets by HPLC. Zhongguo Yiyao Gongye Zazhi, v.35, n.1, p.46-48, 2004.

ZAVIS, H.; LUDVIK, D.; MILAN, K.; LADISLAW, S.; FRANTISCK, V. Handbook of organic reagents in inorganic analysis. New York: John Wiley \& Sons, 1976. p.364.

Received for publication on $4^{\text {th }}$ September 2008 Accepted for publication on $8^{\text {th }}$ January 2009 